\title{
High acrylate concentrations in the mucus of Phaeocystis globosa colonies
}

\author{
Diana J. B. Noordkamp ${ }^{1, *}$, Michiel Schotten ${ }^{2}$, Winfried W. C. Gieskes ${ }^{2}$, \\ Larry J. Forney ${ }^{1}$, Jan C. Gottschal ${ }^{1}$, Marion van Rijssel ${ }^{2}$
}

Department of ${ }^{1}$ Microbiology and ${ }^{2}$ Marine Biology, University of Groningen, PO Box 14, 9750 AA Haren, The Netherlands

\begin{abstract}
Acrylate produced from dimethylsulphoniopropionate (DMSP) by Phaeocystis has been claimed to inhibit bacterial growth. However, the concentrations of acrylate measured in seawater during Phaeocystis blooms are not high enough to expect inhibition of bacterial growth. In this study, the total acrylate in Phaeocystis cultures free from bacteria was measured. The concentration found in the exponential phase of growth was similar $(0.1$ to $1.0 \mu \mathrm{M})$ to earlier field reports, but the amount found in the stationary phase of growth was much higher ( 1 to $4 \mu \mathrm{M}$ ). Acrylate in cultures, as well as in field samples, was found to be located in the mucous layer of the colony. 'Microscale' concentrations in that layer were more than 1000 -fold higher $(1.3$ to $6.5 \mathrm{mM})$ than the total concentration found in the unfractionated culture. Such high concentrations could have an antimicrobial effect. However, acrylate appears to be adsorbed to the mucus and may be inaccessible to bacteria, including those that consume acrylate. As soon as the colonies started to decay, acrylate was released into the surrounding environment, and since it is not detected in bloom samples, it is apparently consumed by bacteria.
\end{abstract}

KEY WORDS: Phaeocystis · Bacteria - Acrylate Colonies Mucus - DMSP - Inhibition

\section{INTRODUCTION}

Phaeocystis (Prymnesiophyceae) is a colony-forming microalga with a world-wide distribution and is well known for its massive blooms (Lancelot et al. 1987). During such blooms most of the cells are present in the palmelloid phase of the life cycle during which they are organised in colonies that consist of cells embedded in a transparent mucous matrix (Rousseau et al. 1990). Young and healthy Phaeocystis colonies are remarkably free of bacteria, and acrylate production by this alga has been suggested to be the reason for this phenomenon (Davidson \& Marchant 1987, Verity et al. 1988, van Boekel et al. 1992). In early field studies, Sieburth (1960), and later Guillard and Hellebust (1971), reported on the production of acrylate by Phaeocystis, causing sterile guts in penguins. Moreover several authors have suggested that acrylate acts as an antibacterial defence strategy during an algal bloom (Sieburth 1959, 1961, Davidson \& Marchant

·E-mail: d.j.b.noordkamp@biol.rug.nl
1987, Verity et al. 1988). However, close coupling between bacterial activity (thymidine incorporation, exoproteolytic activity and direct substrate utilisation) and primary production of Phaeocystis was found (Lancelot \& Billen 1984, Billen \& Fontigny 1987). Also a microscopy study of bacteria revealed an increase in bacterial abundance and cell size during the initial phases of the bloom (Putt et al. 1994). Thus, the antimicrobial effect of acrylate in the marine environment remains under debate.

Acrylate in the marine environment is mainly derived from the degradation of dimethylsulphoniopropionate (DMSP), which serves as an osmolyte (Kirst 1989) and possibly as a cryoprotectant (Kirst 1996) of marine algae. Phaeocystis produces large amounts of intracellular DMSP (Keller et al. 1989, Keller 1991, Stefels \& van Boekel 1993), and has an extracellularly located, membrane bound DMSP-lyase which cleaves DMSP into equimolar amounts of acrylate and dimethyl sulphide (DMS) (Stefels \& Dijkhuizen 1996).

Acrylate concentrations from $100 \mu \mathrm{M}$ to $532 \mathrm{mM}$ are inhibitory for a range of different bacteria depending 
on the pH used (Sieburth 1960, Slezak et al 1994). Total acrylate concentrations in the open ocean, however, only appear to be in the nM range (Gibson et al. 1996) but may reach values as high as $1.21 \mu \mathrm{M}$ (Gibson et al. 1996) and 0.51 to $0.7 \mu \mathrm{M}$ for Phaeocystis blooms (Yang et al. 1994, Osinga et al. 1996). Thus, the maximum total concentrations of acrylate measured in the marine environment are far too low to expect inhibition of bacteria. Hence, Slezak et al. (1994) proposed that inhibition by acrylate could only play a role under the specific condition of phytoplankton aggregate formation, e.g. in marine snow or colonies, where acrylate can be enriched more than 1000 -fold compared to the surrounding seawater.

Recently van Rijssel et al. (1997) showed that the mucus in Phaeocystis colonies is not evenly distributed over the whole colony, but is concentrated in a thin $7 \mu \mathrm{m}$ thick outer layer of the colony in which the algal cells are embedded. If the acrylate produced is located in this thin layer of mucus, it could be that concentrations 'on a microscale' are high enough to potentially inhibit growth of marine bacteria, or, as suggested by Wolfe et al. (1997), act as an anti-predation agent. The purpose of this study was to determine the amount of acrylate produced by Phaeocystis, and to elucidate the location and possible 'microscale' accumulation of acrylate in the mucous layer of the colony.

\section{MATERIAL AND METHODS}

Algal strains and culturing conditions. Two axenic colony-forming Phaeocystis strains that had been previously isolated from the Dutch Coastal Zone by L. Peperzak (Strain L) and I. Janse (Strain I) were used. Both strains make 'globosa' type colonies in which cells are randomly located along the periphery of the colony (Baumann et al. 1994). The medium used was filtered (Whatman GF/D) seawater that had been collected near Iceland, and was supplemented with additions as described by Admiraal \& Werner (1983), except for the vitamin solution which was taken from Veldhuis \& Admiraal (1987). All media components were sterilised by autoclaving except for the vitamins, which were filter sterilised $(0.2 \mu \mathrm{m})$. After inoculation with algae, the cultures were incubated on a rolling device $(8 \mathrm{rpm})$ at $11^{\circ} \mathrm{C}$, at a photon flux density of $40 \mu \mathrm{mol} \mathrm{m} \mathrm{m}^{-2} \mathrm{~s}^{-1}$ (measured with a cosine collector), with a day:night cycle of 14:10 h. Stock cultures were kept at $4^{\circ} \mathrm{C}$.

Field samples of algae were taken during the spring bloom of Phaeocystis in 1997. During this period, surface water samples were taken with a bucket in the Marsdiep off Texel, The Netherlands. The samples were stored cold $\left(4^{\circ} \mathrm{C}\right)$ and analysed the same day.
Enumeration of cells. Algal cells were counted with an inverted microscope (Zeiss), using the Utermöhl sedimentation technique (Utermohi 1958) after fixation with acid Lugol solution. Possible bacterial contamination of the axenic algal strains was checked microscopically on a regular basis. The samples were filtered through a $0.2 \mu \mathrm{m}$ nucleopore filter (Hobbie et al. 1977). Filters were examined with an epifluorescence microscope after staining with Hoechst dye no. 33258 (Paul 1982). No bacterial contamination was detected during the experiments with axenic cultures.

Acrylate and DMSP analyses. Phosphoric acid (1\% $\mathrm{v} / \mathrm{v})$ was added to the samples used for acrylate determinations immediately after they were taken. This lowers the $\mathrm{pH}$ to 1 which was sufficient to inactivate the DMSP-lyase present in the culture. The samples were then vigorously mixed to homogenise the acrylate and subsamples were taken and frozen at $-20^{\circ} \mathrm{C}$ until analysis. For DMSP analyses, $1 \mathrm{ml}$ samples were supplemented with $100 \mu 10 \mathrm{M} \mathrm{NaOH}$, incubated for $24 \mathrm{~h}$ at $4^{\circ} \mathrm{C}$, neutralised with $100 \mu 10 \mathrm{M} \mathrm{HCl}$, acidified with phosphoric acid $(1 \% \mathrm{v} / \mathrm{v})$, and stored at $-20^{\circ} \mathrm{C}$. After thawing and homogenising, the samples were centrifuged $(10000 \times g, 5 \mathrm{~min})$ and the supernatant was used for analysis. Analyses were performed on a Pharmacia HPLC system equipped with a Econosil C18 $5 \mathrm{U}$ column (Alltech) with MilliQ water containing $7.5 \%$ acetonitrile and $1 \%$ phosphoric acid as the eluent at a flow rate of $1.0 \mathrm{ml} \mathrm{min}^{-1}$. Acrylate was quantified spectrophotometrically at $210 \mathrm{~nm}$. Sodium-acrylate (Aldrich Chemicals) was used as a standard. Data were analysed using the EZChrom Data system (Pharmacia).

Acrylate production. The growth of Strain I was followed by determining the cell numbers, acrylate and DMSP in samples of the total culture and on the filtrate of $\mathrm{GF} / \mathrm{F}$ filtered samples (Whatman filters, precombusted for $3 \mathrm{~h}$ at $450^{\circ} \mathrm{C}$ ). Duplicate samples were analysed. To avoid damage of Phaeocystis cells, only gravity force was used for filtration. The DMSP concentration of various fractions were calculated in the following way:

Synthesised DMSP:

$[\mathrm{DMSP}]_{\text {synth }}=\left[\left.\mathrm{DMSP}\right|_{\text {totâl }}\right.$

Dissolved DMSP:

$[\mathrm{DMSP}]_{\mathrm{diss}}=[\mathrm{DMSP}]_{\text {filtrate }}-[\text { acrylate }]_{\text {filtrate }}$

Particulate DMSP:

$$
[D M S P]_{\text {part }}=[D M S P]_{\text {total }}-[\text { acrylate }]_{\text {total }}-[D M S P]_{\text {diss }}
$$

Acrylate location. Where in particulate fraction: During the exponential phase of the growth, colonies of one size $(r=1 \mathrm{~mm})$ were selected from cultures of Strain I and transferred into tubes. Samples without colonies from the original culture were added to obtain an equal volume in each tube. Colony density in the 
tubes varied from 0 to 20 colonies $\mathrm{ml}^{-1}$. Samples for acrylate analyses were taken after vigorous mixing.

Where in colonies: Colonies were harvested at various times during the exponential growth of both axenic strains and from a bloom sample taken in the field. Samples were transferred to a petri dish with a transparent ruler underneath and each colony was measured at $40 \times$ magnification. Colonies, representing different size classes, were removed using a pipette and transferred into test tubes. Only spherical colonies were selected in order to be able to calculate the surface area $\left(4 \pi r^{2}\right)$ and the volume $\left(4 / 3 \pi r^{3}\right)$ from the measured diameter $(d=2 r)$. The number of colonies per tube ranged from 2 to 82 depending on the size class and their abundance in the original sample. Tubes were filled to a known volume ( 2 to $5 \mathrm{ml}$ ) with a subsample without colonies. After vigorous mixing of the tubes, subsamples were taken for acrylate analyses and algal cell counts. A subsample without colonies served as a blank.

To determine whether acrylate was related to the volume or surface of colonies, the logarithm of the dependent variable (acrylate) was plotted against the logarithm of the colony volume (cf. van Rijssel et al. 1997). The equation describing this relationship is:

$$
\log (\text { acrylate })_{\text {colony }}=\alpha \times \log \left(\text { volume }_{\text {colony }}+C\right.
$$

wherein $\alpha$ is the slope of the line and $C$ a constant. The value $\alpha$ is $2 / 3$ in the case of a surface related variable and 1 in the case of a volume related variable.

\section{RESULTS}

\section{Production of acrylate}

The production of acrylate was followed during batch cultivation of an axenic colony-forming strain of Phaeocystis (Fig. 1A). Total acrylate concentrations rose above the detection limit $(0.1 \mu \mathrm{M})$ on Day 6 , and continued to increase to $1.0 \mu \mathrm{M}$ at the onset of the stationary phase and to $4.3 \mu \mathrm{M}$ during the senescent phase. This was in contrast to measurements that had been taken in the field where the total acrylate concentration detected in the senescent phase of blooms quickly dropped to zero (Yang et al. 1994, Osinga et al. 1996). The non-linear regression curve $\left(r^{2}=0.98\right)$ of the total concentration of acrylate versus time was used to calculate acrylate production rates (Fig. 1A, B). These were 0.6 to $0.8 \mathrm{fmol} \mathrm{cell}^{-1} \mathrm{~d}^{-1}$ in the exponential phase of growth (Days 7 to 10), and increased during the senescent phase of growth up to $2.8 \mathrm{fmol} \mathrm{cell}^{-1} \mathrm{~d}^{-1}$ (Day 15). These results show that the absence of acrylate at the end of the bloom is not due to lack of acrylate production.
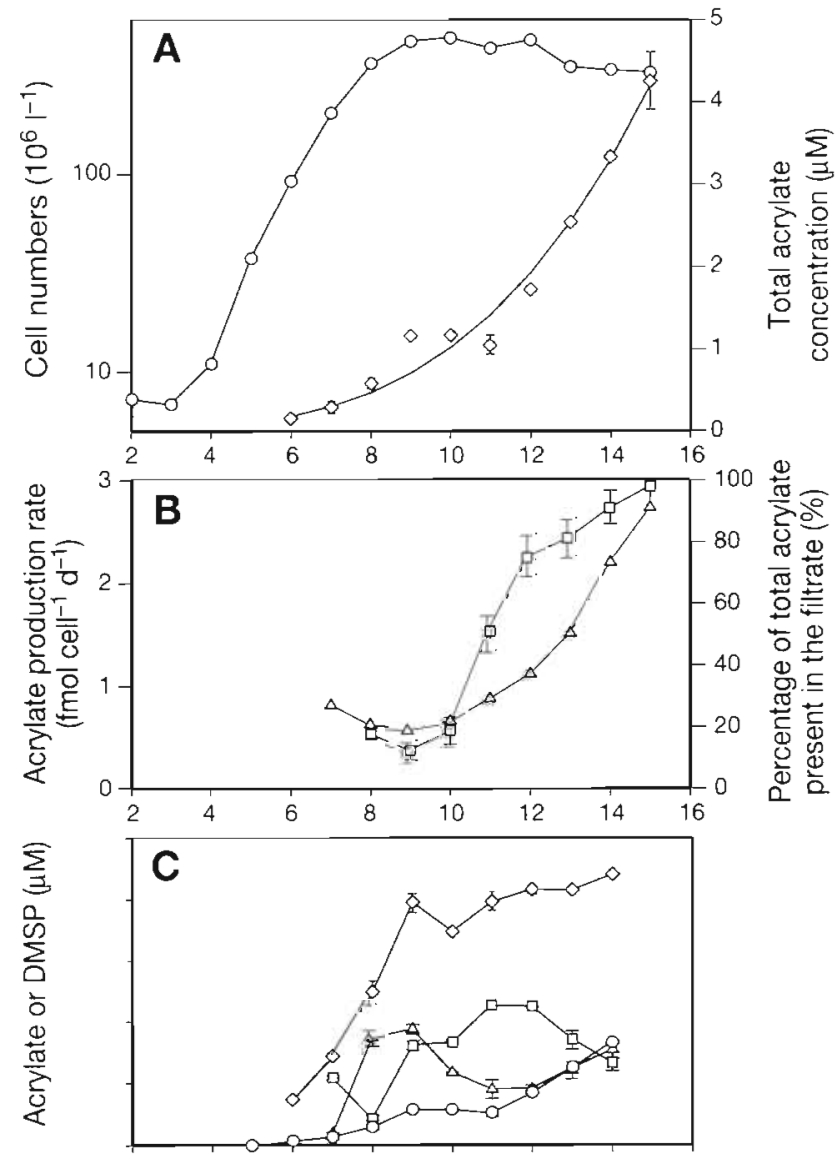

Time (d)

Fig. 1. (A) Growth curve of colony forming Phaeocystis Strain I, algal cells $(0)$, total acrylate concentration ( () ), non-linear regression curve for the total acrylate concentration $(-)\left(\mathrm{r}^{2}=\right.$ $0.98)$. (B) Calculated total acrylate production rates $(\Delta)$, percentage of total acrylate present in the filtrate ( $\square$ ). (C) Concentration $(\mu \mathrm{M})$ of particulate DMSP (DMSP ${ }_{\text {part }}$ ), dissolved DMSP (DMSP diss ), and total acrylate $(0)$ during the growth of the axenic colony forming Phaeocystis Strain I. The different DMSP values were calculated in the following way: DMSP diss $(\square)=[D M S P]_{\text {filtrate }}-[\text { acrylate }]_{\text {ititratei }} \operatorname{DMSP}_{\text {synth }}(\diamond)=[D M S P]_{\text {totali }}$ $\operatorname{DMSP}_{\text {part }}(\Delta)=[D M S P]_{\text {total }}-[\text { acrylate }]_{\text {total }}-[D M S P]_{\text {diss }}$

The concentration of DMSP was measured to establish whether the increased acrylate production rate in the stationary phase of growth (Fig. 1B) was caused by the increased cellular production of DMSP and subsequent excretion of acrylate, or by lysis of Phaeocystis cells. The latter could result in DMSP leakage and subsequent increased conversion into DMS and acrylate by extracellular DMSP-lyase. The rate of total acrylate production increased after Day 11 while dissolved DMSP decreased, indicating that $\mathrm{DMSP}_{\text {diss }}$ is converted to DMS and acrylate. The increased concentration of $\mathrm{DMSP}_{\text {synth }}$ at the end of the stationary phase indicated that production of DMSP is still continued. 
These results suggest that the increased acrylate production rate during the stationary phase is due to both cellular excretion of acrylate as well as lysis of Phaeocystis cells.

\section{Acrylate in colonies}

In the exponential phase of growth, only $12.5 \%$ of the total acrylate was detected in the filtrate, and this increased in the stationary phase to $98 \%$ (Day 15) (Fig. 1B). This suggests that the acrylate produced during the exponential growth phase was associated with either the cells or the colonies.

To distinguish between the association of acrylate with colonies or cells of Phaeocystis, tubes with different colony densities were obtained by collecting colonies from an exponentially growing axenic culture of Phaeocystis. Subsequent determination of the total acrylate content in each tube revealed (Fig. 2) that the amount of acrylate increased as the colony density increased, suggesting that the acrylate was associated with the colonies and not with single, individual non-colonial cells. This conclusion is important for future total acrylate measurements in the field during blooms of Phaeocystis because filtration steps will result in underestimates of the total acrylate produced.

\section{Location of acrylate}

Double logarithmic plots of acrylate versus the volume of colonies of different sizes were determined in order to establish whether acrylate is uniformly dis-

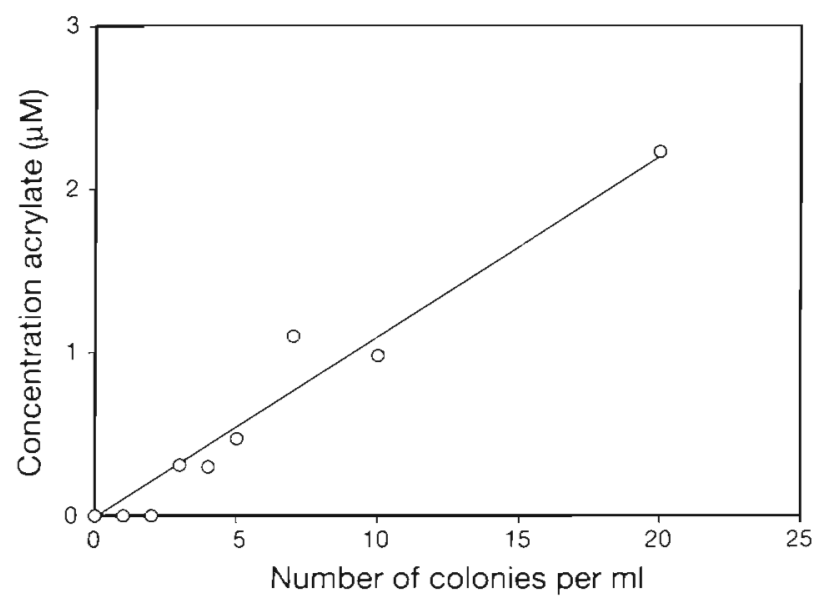

Fig. 2. Acrylate concentrations $(\mu \mathrm{M})$ of samples containing different numbers of colonies ( $r=1 \mathrm{~mm}$ ) per $\mathrm{ml}$ from an exponentially growing Phaeocystis Strain I. Linear regression line $y=0.12 x-0.08, r^{2}=0.96$ tributed throughout the entire colony or only present in the mucous layer. Colonies were taken from exponentially growing cultures of 2 axenic strains of Phaeocystis and from a bloom sample from the field. They were sorted into different size classes and the total acrylate content was determined. The 7 data sets obtained (Fig. 3A-C) were subjected to ANCOVA tests. The slope of linear regression lines from laboratory cultures and field samples (Fig. 3) were not significantly different from each other $\left(F_{6,23}=1.49, \mathrm{p}=\right.$ $0.226)$. The slope was $0.55\left(F_{1,29}=4.01, \mathrm{p}<0.001\right)$ with a $95 \%$ confidence interval ranging from 0.45 to

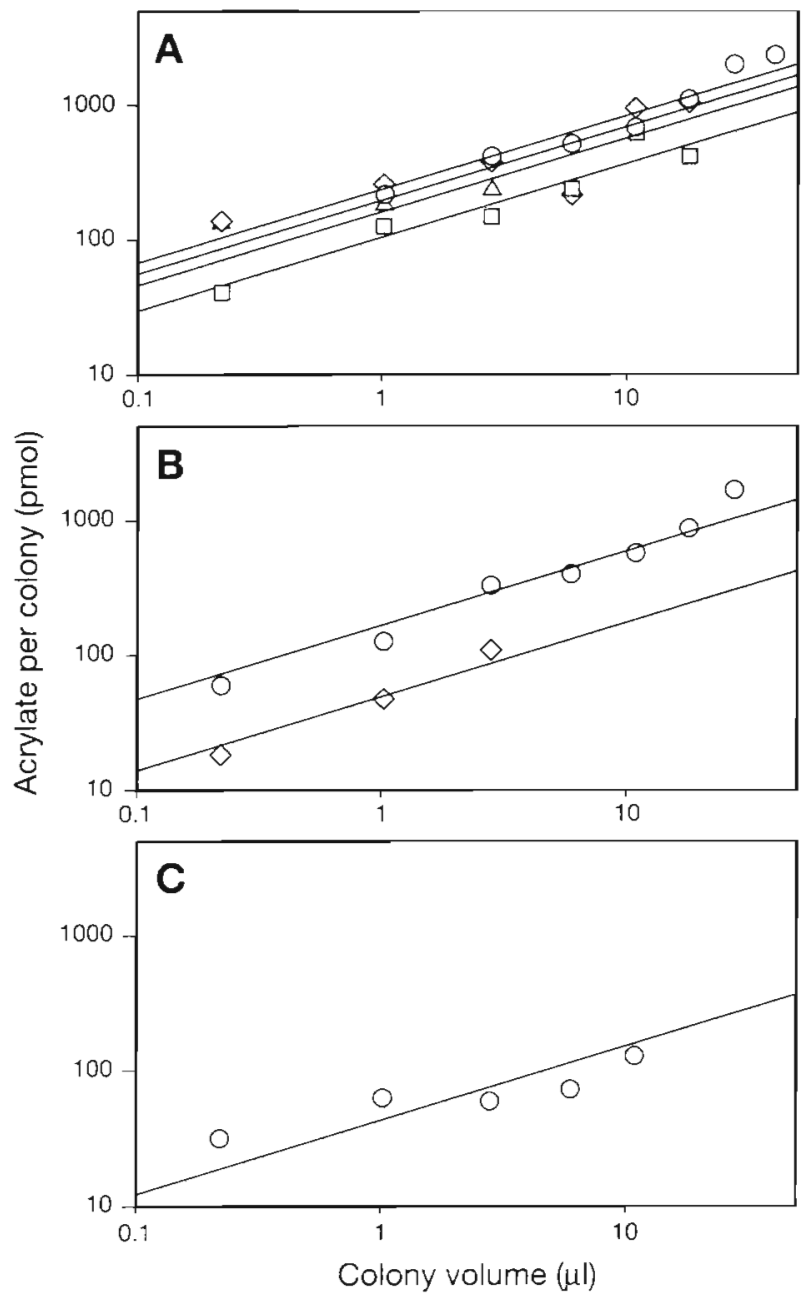

Fig. 3. Correlation between volume of a colony and amount of acrylate in that colony (log acrylate $=0.55 \log$ volume $+b)$ in different stages of the logarithmic phase for 2 axenic Phaeocystis strains and a field sample from a Phaeocystis bloom. Each point is the average of a number of colonies (Table 1). Variation was between 1 and $5 \%$. (A) Axenic Strain L, early logarithmic phase, $b=2.29(\Delta)$, early mid logarithmic phase $b=2.20(0)$, late mid logarithmic phase, $b=2.02(\square)$, end logarithmic phase, $b=2.37$ (O). (B) Axenic Strain I, early mid logarithmic phase, $b=1.70(\diamond)$, end logarithmic phase, $b=2.22(0)$ (C) Field sample, $b=1.63(0)$ 
Table 1. Number of colonies per size class for Strain L, Strain I, and the field sample at different times in the exponential phase of growth

\begin{tabular}{|c|c|c|c|c|c|c|c|c|}
\hline $\begin{array}{l}\text { Size class } \\
\text { (diameter, mm) }\end{array}$ & $\begin{array}{c}\text { Colony volume } \\
\left(\mu l=\mathrm{mm}^{3}\right\}\end{array}$ & Strain, $L^{d}$ & $\begin{array}{l}\text { Num } \\
\text { Strain, } L^{b}\end{array}$ & $\begin{array}{l}\text { per of color } \\
\text { Strain, } L^{C}\end{array}$ & $\begin{array}{l}\text { ies per size } \\
\text { Strain, } L^{d}\end{array}$ & $\begin{array}{l}\text { lass } \\
\text { Strain, } I^{b}\end{array}$ & Strain, ${ }^{d}$ & Field \\
\hline $0.5-1.0$ & 0.2 & 82 & 72 & 41 & & 23 & 41 & 61 \\
\hline $1.0-1.5$ & 1.0 & 31 & 66 & 48 & 37 & 19 & 46 & 32 \\
\hline $1.5-2.0$ & 2.8 & 13 & 39 & 39 & 39 & 11 & 19 & 24 \\
\hline $2.0-2.5$ & 6.0 & 2 & 8 & 33 & 33 & & 10 & 13 \\
\hline $2.5-3.0$ & 10.9 & & 4 & 30 & 25 & & 9 & 5 \\
\hline $3.0-3.5$ & 18.0 & & 4 & 5 & 14 & & 3 & \\
\hline $3.5-4.0$ & 27.6 & & & & 6 & & 4 & \\
\hline $4.0-4.5$ & 40.2 & & & & 6 & & & \\
\hline
\end{tabular}

0.65. Moreover the slopes did not vary with different stages of growth, but they did reflect a significant difference in level of acrylate per colony $\left(F_{6,29}=12.31\right.$, $p<0.001)$. Colonies from the laboratory experiments contained significantly more acrylate compared to the bloom sample except for colonies from Strain $I$ in the exponential phase $\left(F_{1,29}=4.01, \mathrm{p}=0.621\right)$. Moreover the slopes were closer to 0.67 than to 1 , so it was concluded that the acrylate was located at the periphery of the colony.

\section{DISCUSSION}

Our results show that the absence of acrylate at the end of Phaeocystis blooms is not due to lack of acrylate production. Indeed, the production of acrylate increased during the stationary phase of growth of Phaeocystis due to both cellular excretion of acrylate as well as lysis of Phaeocystis cells. Moreover, the data show that the acrylate produced in the logarithmic phase of growth was associated with the colonies and located in the thin mucous layer in which the algal cells were embedded. That acrylate is located in the mucous layer was concluded from the relationship between colony volume and acrylate content (Fig. 3). Acrylate seems to correlate with the surface area of the colony and not the volume in both axenic strains and field samples. However, the slope of the regression line, 0.55 (Eq. 1), was less than the theoretically expected value of 0.67 :

$$
\log \text { acrylate }=0.55 \log \text { volume }+C
$$

Previously measured slopes of double-logarithmic plots of a number of other variables versus colony volume in Phaeocystis were also always lower than the expected $2 / 3$ for surface-related variables as shown by van Rijssel et al. (1997; Eqs. 2 \& 3), Rousseau et al. (1990; Eq. 4), and Weisse \& Scheffel-Möser (1990; Eq. 5): log sugar $=0.46 \log$ volume -0.06

$\log$ carbon $=0.44 \log$ volume -0.19

log cell number $=0.51 \log$ volume +3.67

log cell number $=0.58 \log$ volume +3.67

Van Rijssel et al. (1997) suggested that the cells become distributed more thinly over the surface when the size of the colony increases. Therefore the number of cells (and thus also the concentration of acrylate, sugar, or carbon) per unit of surface area will be lower in larger colonies, and consequently slope $\alpha$ of the regression line will be less. Indeed, when the numbers of cells per $\mathrm{mm}^{2}$ in colonies of different sizes was measured they were found to decrease when the size of colonies increased (Fig. 4). Therefore, we think it is appropriate to conclude that the acrylate in young and healthy colonies is correlated with the colony surface.

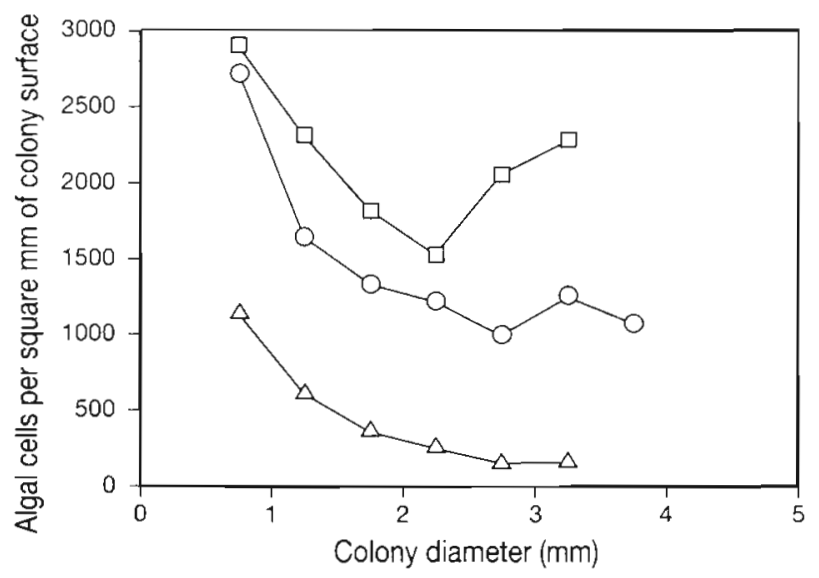

Fig. 4. Colony diameter plotted against algal cells per $\mathrm{mm}^{2}$ of colony surface for 2 strains of Phaeocystis during exponential growth and a field sample from a Phaeocystis bloom. (O) Strain L-early mid logarithmic phase, () Strain I-end logarithmic phase, $(\Delta)$ field sample 
Table 2. Calculated 'microscale' acrylate concentrations in the mucous layer of Phaeocystis colonies

\begin{tabular}{|lcc|}
\hline $\begin{array}{l}\text { Phaeocystis } \\
\text { strain }\end{array}$ & $\begin{array}{c}\text { Moment in the } \\
\text { logarithmic phase }\end{array}$ & $\begin{array}{c}\text { Concentration acrylate } \\
\mathrm{mM} \text { (error) }\end{array}$ \\
\hline Field & Beginning & $1.34( \pm 0.37)$ \\
Strain L & Early & $6.52( \pm 2.23)$ \\
Strain L & Early mid & $6.07( \pm 1.27)$ \\
Strain L & Late mid & $2.81( \pm 0.35)$ \\
Strain L & End & $5.46( \pm 0.37)$ \\
Strain I & Early mid & $1.50( \pm 0.07)$ \\
Strain I & End & $4.21( \pm 0.30)$ \\
\end{tabular}

\section{Concentration of acrylate in the mucous layer}

The colony surface consists of a $7 \mu \mathrm{m}$ thick mucous layer (van Rijssel et al. 1997), and therefore it is reasonable to assume that the surface-associated acrylate is located in that layer. Data from Fig. 3 were used to calculate 'microscale' acrylate concentrations in that mucous layer (Table 2). Concentrations varied from 2.8 to $6.5 \mathrm{mM}$ for Strain $\mathrm{L}$ and 1.5 to $4.2 \mathrm{mM}$ for Strain I. The acrylate concentration in the bloom sample was $1.3 \mathrm{mM}$, similar to the lowest value of the laboratory strains. On the basis of our data it cannot be determined whether the somewhat lower 'microscale' acrylate concentration in the field samples (Table 2) is caused by loss of acrylate from the colonies in the field, or that acrylate formation in the field is slightly lower than in axenic laboratory cultures. Nonetheless the 'microscale' concentrations in all samples were in the mM range and therefore may be high enough to cause inhibition of bacterial growth (Sieburth 1960, Slezak et al. 1994).

\section{Acrylate in the field}

In field studies, acrylate is detected in the beginning of the bloom, but as the bloom reaches the senescent phase, acrylate concentrations quickly drop to zero (Yang et al. 1994, Osinga et al. 1996). Davidson \& Marchant (1987) have suggested that bacteria are able to invade old and senescent colonies because acrylate would only be produced in the exponential phase of growth. However, data obtained in this study using axenic cultures (Fig. 1) showed there was an increased rate of acrylate production in the senescent phase, and the concentration of acrylate in the colonies was much higher than in the surrounding medium (Fig. 1B). Bearing in mind that many marine bacteria are known to metabolise acrylate (Kiene 1990, Taylor \& Gilchrist 1991, Diaz et al. 1992, Ledyard et al. 1993), we suggest that the absence of acrylate in the senescent phase of Phaeocystis blooms is due to bacterial consumption of acrylate rather than lack of its production.

Maximum concentrations of total acrylate reported for Phaeocystis in the field range between 0.51 and $0.7 \mu \mathrm{mol} \mathrm{l} \mathrm{l}^{-1}$ (Yang et al. 1994, Osinga et al. 1996). These values are comparable to the total acrylate concentrations measured in the medium of axenic cultures during exponential growth of cells in the present study $\left(0.1\right.$ to $\left.1.0 \mu \mathrm{mol} \mathrm{l}^{-1}\right)$. Also the 'microscale' concentration of acrylate in the colony mucous layer is practically the same for field and axenic laboratory strains. This suggests that the presence of bacteria in the field has little influence on the acrylate concentration found at the beginning of the bloom.

\section{Function of acrylate}

Sieburth (1968) proposed that products excreted by algae create a concentration gradient outside the cell, as was also suggested by Azam et al. (1983). Our data indicate that such a gradient could exist outwards from the mucous layer of Phaeocystis colonies in the field. The high concentrations of acrylate might inhibit bacteria in the vicinity of colonies, because mM concentrations of acrylate can be enough to inhibit bacterial growth (Sieburth 1960, Slezak et al. 1994).

Besides inhibiting bacteria, acrylate could also be a nuisance to other organisms such as predators. Recently Wolfe et al. (1997) found that strains of Emiliania huxleyi with low DMSP-lyase were preferred by predators over strains with high DMSP-lyase. They suggested that increased levels of acrylate, formed from the internal DMSP pool by DMSP-lyase in E. huxleyi, was responsible. Their video analysis suggests that the protozoan Oxyrrhis marina reacts to increasing acrylate concentrations with an increased rate of change in direction. Acrylate located in the mucous layer of Phaeocystis could act in a similar way as an anti-predation agent. It is known that healthy colonies are not grazed upon (Estep et al. 1990), and that other algae are preferred over Phaeocystis (Hansen 1995).

As to interactions with bacteria one cannot exclude the possibility that acrylate is inaccessible to these microorganisms because it may be ionically bound inside the mucus. Phaeocystis mucus consists of more than 8 different sugars and some negatively charged uronic acids (Janse et al. 1996) which are ionically linked by positively charged ions such as manganese and calcium (van Boekel et al. 1992). Thus the negatively charged acrylate could also be ionically bound to the mucus via such salt bridges. If this is the case, then acrylate is neither harmful nor accessible as a growth substrate during the exponential growth of Phaeocystis colonies because it is biologically unavailable. 
Hence, acrylate could act as a defence mechanism against bacteria or, at a higher trophic level, as protection against predation. Alternatively, it could also be rather harmless as a delayed carbon source for bacteria. To substantiate these possibilities, further studies with defined cocultures are in progress.

Acknowledgements. The authors thank Maarten J. J. E. Loonen from the Zoological Laboratory for statistical analysis of the data and Jacqueline Stefels from the Marine Biology Department for valuable discussions.

\section{LITERATURE CITED}

Admiraal W, Werner D (1983) Utilisation of limiting concentrations of ortho-phosphate and production of extracellular organic phosphates in cultures of marine diatoms. J Plankton Res 5:495-513

Azam F, Fenchel T, Field JG, Gray JS, Meyer-Reil LA, Thingstad $F$ (1983) The ecological role of water column microbes in the sea. Mar Ecol Prog Ser 10:257-263

Baumann MEM, Lancelot C, Bardini FP, Sakshaug E, John DM (1994) The taxonomic identity of the cosmopolitan prymnesiophyte Phaeocystis; a morphological and ecophysiopolgical approach. In: Lancelot C, Wassmann P (eds) The ecology of Phaeocystis dominated systems. J Mar Syst 5:5-22

Billen G, Fontigny A (1987) Dynamics of a Phaeocystis-dominated spring bloom in Belgian coastal waters. II. Bacterioplankton dynamics. Mar Ecol Prog Ser 37:249-257

Davidson AT, Marchant HJ (1987) Binding of manganese by Antarctic Phaeocystis pouchetii and the role of bacteria in its release. Mar Biol 95:481-487

Diaz MR, Visscher PT, Taylor BF (1992) Metabolism of dimethylsulfoniopropionate and glycine betaine by a marine bacterium. FEMS Microbiol Lett 96:61-66

Estep KW, Nejstgaard J, Skjoldal HR, Rey F (1990) Predation by copepods upon natural populations of Phaeocystis pouchetii as a function of the physiological state of the prey, Mar Ecol Prog Ser 67:235-249

Gibson JAE, Swadling KM, Burton HR (1996) Acrylate and dimethylsulfoniopropionate (DMSP) concentrations during an Antarctic phytoplankton bloom. In: Kiene RP, Visscher PT, Keller MD, Kirst GO (eds) Biological and environmental chemistry of DMSP and related sulfonium compounds. Plenum Press, New York, p 213-222

Guillard RRL, Hellebust JA (1971) Growth and the production of extracellular substances by two strains of Phaeocystis pouchetii. J Phycol 7:330-338

Hansen FC (1995) Trophic interactions between zooplankton and Phaeocystis cf. globosa. Helgoländer Meeresunters 49:283-293

Hobbie JE, Daley RJ, Jasper S (1977) Use of nucleopore filters for counting bacteria by fluorescence microscopy. A.ppl Environ Microbiol 33(5):1225-1228

Janse I, van Rijssel M, Gottschal JC, Lancelot C, Gieskes WWC (1996) Carbohydrates in the North Sea during spring blooms of Phaeocystis: a specific fingerprint. Aquat Microb Ecol 10:97-103

Keller MD (1991) Dimethyl sulphide production and marine phytoplankton: the importance of species composition and cell size. Biol Oceanogr 6:375-382

Keller MD, Bellows WK, Guillard RRL (1989) Dimethyl sulfide production in marine phytoplankton. In: Saltzman ES,
Cooper WJ (eds) Biogenic sulfur in the environment Vol 393. American Chemical Society, Washington, DC, p $167-182$

Kiene RP (1990) Dimethyl sulfide production from dimethylsulfoniopropionate in coastal seawater samples and bacterial cultures. Appl Environ Microbiol 56(11):3292-3297

Kirst GO (1989) Salinity tolerance of eukaryotic marine algae. Annu Rev Plant Physiol Plant Mol Biol 40:21-53

Kirst GO (1996) Osmotic adjustment in phytoplankton and macroalgae: the use of dimethylsulfoniopropionate (DMSP) In: Kiene RP, Visscher PT, Keller MD, Kirst GO (eds) Bioogical and environmental chemistry of DMSP and related sulfonium compounds. Plenum Press, New York, p 21-129

Lancelot C, Billen G (1984) Activity of heterotrophic bacteria and its coupling to primary production during the spring phytoplankton bloom in the southern bight of the North Sea. Limnol Oceanogr 29(4):721-730

Lancelot C, Billen G, Sournia A, Weisse T, Colijn F, Veldhuis MJW, Davies A, Wassmann P (1987) Phaeocystis blooms and nutrient enrichment in the coastal zones of the North Sea. Ambio 16:38-46

Ledyard KM, DeLong EF, Dacey JWH (1993) Characterization of a DMSP-degrading bacterial isolate from the Sargasso Sea. Arch Microbiol 160:312-318

Osinga R, Kwint RLJ, Lewis WE, Kraay GW, Lont JD, Lindeboom HJ, van Duyl FC (1996) Production and fate of Phaeocystis, dimethylsulfide and dimethylsulfoniopropionate in pelagic mesocosms: the role of sedimentation. Mar Ecol Prog Ser 131:275-286

Paul JH (1982) Use of Hoechst dyes 33258 and 33342 for enumeration of attached and planktonic bacteria. Appl Environ Microbial 43(4):939-944

Putt M, Micelli G, Stoecker DK (1994) Association of bacteria with Phaeocystis sp. in McMurdo Sound Antarctica. Mar Ecol Prog Ser 105:179-189

Rousseau V, Mathot S, Lancelot C (1990) Calculating carbon biomass of Phaeocystis sp. from microscopic observations. Mar Biol 107:305-314

Sieburth JMCN (1959) Antibacterial activity of antartic marine phytoplankton. Limnol Oceanogr 4:419-424

Sieburth JMcN (1960) Acrylic acid, an 'antibiotic' principle in Phaeocystis blooms in antarctic waters. Science 132: 676-677

Sieburth JMcN (1961) Antibiotic properties of acrylic acid, a factor in the gastrointestinal antibiosis of polar marine animals. J Bacteriol 82:72-79

Sieburth JMCN (1968) The Influence of algal antibiosis on the ecology of marine microorganisms. In: Droop MR, Ferguson, Wood EJ (eds) Advances in microbiology of the sea, Vol 1. Academic Press, New York, p 63-94

Slezak DM, Puskaric S, Herndl GJ (1994) Potential role of acrylic acid in bacterioplankton communities in the sea. Mar Ecol Prog Ser 105:191-197

Stefels J, Dijkhuizen L (1996) Characteristics of DMSP-lyase in Phaeocystis sp. (Prymnesiophyceae). Mar Ecol Prog Ser 131:307-313

Stefels J, van Boekel WHM (1993) Production of DMS from dissolved DMSP in axenic cultures of the marine phytoplankton species Phaeocystis sp. Mar Ecol Prog Ser 97: $11-18$

Taylor BF, Gilchrist DC (1991) New routes for aerobic biodegradation of dimethylsulfoniopropionate. Appl Environ Microbiol 57(12):3581-3584

Utermöhl H (1958) Zur Vervollkommnung der quantitativen Phytoplankton-Methodik. Mitt Int Verein Theor Angew Limnol 9:1-38 
van Boekel WHM, Hanse FC, Riegman R, Bak RPM (1992) Lysis-induced decline of a Phaeocystis spring bloom and coupling with the microbial foodweb. Mar Ecol Prog Ser $81: 269-276$

van Rijssel M. Hamm CE. Gieskes WWC (1997) Phaeocystis globosa (Prymnesiophyceae) colonies: hollow structures built with small amounts of polysaccharides. Eur J Phycol $32: 185-192$

Veldhuis MJW, Admiraal W (1987) The influence of phosphate depletion on the growth and colony formation of Phaeocystis pouchetii (Hariot) Lagerheim. Mar Biol 95: $47-54$

Verity PG, Villareal TA, Smayda TJ (1988) Ecological investigations of blooms of colonial Phaeocystis pouchetii. II. The

Editorial responsibility: Patricia Glibert,

Cambridge, Maryland, USA role of life-cycle phenomena in bloom termination. J Plankton Res 10(4):749-766

Weisse T, Scheffel-Möser U (1990) Morphometric characteristics and carbon content of Phaeocystis cf. pouchetii (Prymnesiophyceae). Botanica Mar 33:197-203

Wolfe GV, Steinke M, Kirst GO (1997) Grazing-activated chemical defence in a unicellular marine alga. Nature 387 : 894-897

Yang H, McTaggart AT, Davidson AT, Burton H (1994) Measurement of acrylic acid and dimethylsulfide in antarctic coastal water during a summer bloom of Phaeocystis pouchetii. In: Hoshiai T (ed) Proceedings of the NIPR Symposium of Polar Biology, Vol 7. National Institute of Polar Research, Tokyo, p 43-52

Submitted: October 30, 1997; Accepted: May 25, 1998 Proofs received from author(s): September 25, 1998 